\title{
Early Devonian (Late Emsian) shark fin remains (Chondrichthyes) from the Paraná Basin, southern Brazil
}

\author{
MARTHA RICHTER ${ }^{1}$, ELVIO P. BOSETTI ${ }^{2}$ and RODRIGO S. HORODYSKI ${ }^{3}$ \\ ${ }^{1}$ Natural History Museum, Department of Earth Sciences, Cromwell Road, London SW7 5BD, United Kingdom \\ ${ }^{2}$ Programa de Pós-Graduação em Geografia, Universidade Estadual de Ponta Grossa, Departamento \\ de Geociências, Av. Carlos Cavalcanti, 1048, Bloco L, 84030-900 Ponta Grossa, PR, Brazil \\ ${ }^{3}$ Programa de Pós-Graduação em Geologia, Universidade do Vale do Rio dos Sinos, \\ Av. Unisinos, 950, Cristo Rei, 93022-000 São Leopoldo, RS, Brazil
}

Manuscript received on July 21, 2016; accepted for publication on September 29, 2016

\begin{abstract}
We report on the pioneering discovery of Devonian fish remains in the Paraná Basin, which represents the southernmost record of fishes from that period in mainland South America. The material comes from an outcrop at the lower portion of the São Domingos Formation, within Sequence C of the Paraná-Apucarana sub-basin in Tibagi, State of Paraná. Marine invertebrates are abundant in the same strata. The dark colored fish remains were collected in situ and represent natural moulds of partially articulated shark fin rays (radials). No elements such as teeth or prismatic cartilage have been preserved with the fins rays. This can be attributed to the dissolution of calcium-phosphatic minerals at the early stages of fossilization due to diagenetic processes possibly linked to strong negative taphonomic bias. This may have contributed to the fact that fishes remained elusive in the Devonian strata of this basin, despite substantial geological work done in the Paraná State in recent decades. In addition, the scarcity of fish fossils may be explained by the fact that the Devonian rock deposits in this basin originated in a vertebrate impoverished, cold marine environment of the Malvinokaffric Realm, as previously suspected.
\end{abstract}

Key words: Chondrichthyes, Devonian, Gondwana, Paraná Basin, southern Brazil, taphonomy.

\section{INTRODUCTION}

The Devonian was a pivotal time for the evolution of fishes and one in which all the large classes of fishes co-existed. Many of the groups that dominated the seas and continental waters at the time did not survive the end of the Devonian. Notably, placoderms and acanthodians whose remains are relatively abundant in South America

Correspondence to: Martha Richter

E-mail: M.Richter@nhm.ac.uk are among the groups that are confined to the Palaeozoic.

When marine fossils, including brachiopods, molluscs, trilobites, echinoderms, annelids and cnidarians were found in the extensive exposures of rocks of Devonian age in the State of Paraná in southern Brazil (e.g. Clarke 1913, Petri 1948, Lange 1967, Melo 1988, Zabini et al. 2012, Bosetti et al. 2012, Horodyski 2014), many palaeontologists started reporting the strange and apparently inexplicable absence of fossil fishes in these rocks. 
Fernandes and Carvalho (2002) described a tubular burrow from the Ponta Grossa Formation in the State of Mato Grosso as a dipnoiform ichnofossil, but there is not enough evidence for this identification (see also Toledo and Bertini 2005). The only other previously purported vertebrate remain found in the Devonian rocks of the Paraná Basin was an amphibian footprint (Leonardi 1983). However, this was a misidentification (Roček and Rage1994, Fernandes 1996).

Disarticulated chondrichthyan, acanthodians, osteichthyans and placoderm fossils have for decades been reported from Devonian rocks in Bolivia, Colombia, Venezuela and the Falkland Islands (Blieck et al. 1996, Gagnier et al. 1988, 1989, Janvier and Suárez-Riglos 1986, Janvier and Villarroel 2000, Santos 1961, Young et al. 2000, Maisey et al. 2002). Older fish faunas have been recorded in Argentina (Albanesi et al. 1995). In Brazil, Devonian fishes occur in the Amazonas and Parnaíba basins in north and north-eastern Brazil, respectively (Janvier 2007, Janvier and Maisey 2010, Janvier and Melo 1992), therefore it seemed only a matter of time until they were found in southern of Brazil, which finally happen when the new localities became temporarily available during road works in the last few years. The material described herein represents the southern most record of Devonian fishes in mainland South America.

\section{MATERIALS AND METHODS}

The fossil material was collected at an outcrop in the vicinity of the $\mathrm{km} 220$ of highway BR 153 in the municipality of Tibagi, Paraná State in southern Brazil (2438'2,19'S 50²7'40,35'O and UTM22J 54533,28mE 7275485,35mS) (Figure 1). The specimens are deposited in the Laboratory of Stratigraphy and Palaeontology of the State University of Ponta Grossa (UEPG, Ponta Grossa, state of Paraná, southern Brazil).
List of material:

UFPG/DEGEO/MPI 9959: Partially articulated remains of a fin UFPG/DEGEO/MPI 10709: Partially articulated remains of a fin UEPG/ DEGEO/MPI 10548: Partially articulated remains of a fin

Two of the specimens (UEPG/DEGEO MPI 9959 and UEPG/DEGEO MPI 10548) have been micro-CT scanned in Rio de Janeiro, but no additional anatomical information was accessible from the scans, nor further fish material was found inside the rock matrix.

The fieldwork was undertaken over the last ten years along the main section Tibagi-Telêmaco Borba originally described by Bergamaschi (1999), and Tibagi-Alto do Amparo section (Bosetti and Horodyski 2008) as well as at localities comprising the boundary between the Ponta Grossa and São Domingos formations, including the Tibagi Member sensu Oliveira (1912) and Grahn et al. (2013). The fossil material was collected utilizing the taphonomic method described by Ghilardi and Simões (2000) and the taphofacies analyses done observing the criteria established by Speyer and Brett (1986, 1988). The taphonomic methodology consisted in the identification of the skeletal types present in the associations (bivalve, univalve, multi-element) and taphonomic signatures (shelly packing, size selection, fragmentation and disarticulation degree, and bioclast orientation in relation to the bedding plane). Signatures such as abrasion, corrosion and rounding have not been detected in any bioclasts; however, the presence/ absence of those signatures was utilized to interpret the different hydrodynamic/energy regimes present in the basin. We also recorded lithological and sedimentary structures associated with the fossils, based on the interpretations provided by Walker and Plint (1992). We have adapted these methodologies to the situation observed in the Devonian rocks of the Paraná basin. Storm deposits interpretation followed Miller et al. (1988). 


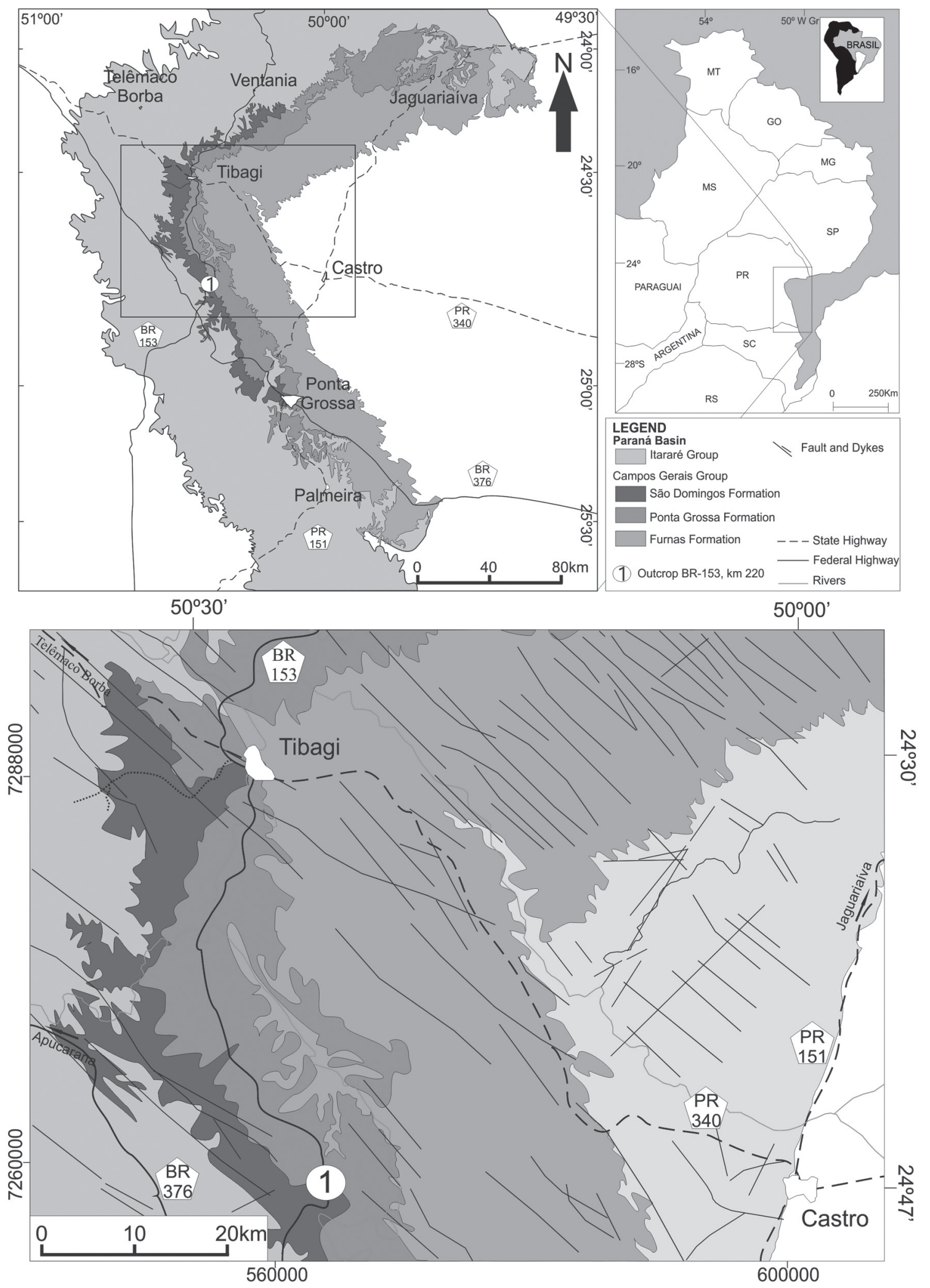

Figure 1 - Location map of the fossiliferous outcrop (1) in the State of Paraná, Brazil. 


\section{GEOLOGICAL SETTING}

The Paraná Basin is a large intracratonic basin (about $1,700,000 \mathrm{~km}^{2}$ ) located in southernmost Brazil and north/northwestern Uruguay, parts of Paraguay and Argentina (Figure 2a). The basin is approximately $1,750 \mathrm{~km}$ long and $900 \mathrm{~km}$ wide, predominantly along a NE-SW axis. The sedimentary fill of the basin was influenced by tectonic-eustatic cycles linked to the evolution of Western Gondwana during the Paleozoic and Mesozoic (Milani and Ramos 1998, Milani et al. 2007).

The basin developed over distinct geotectonic domains, comprising Archean and Early Proterozoic cratonic terranes and Late Proterozoic mobile belts related to the Pan-african and Brazilian cycles that were responsible for the assemblage of Western

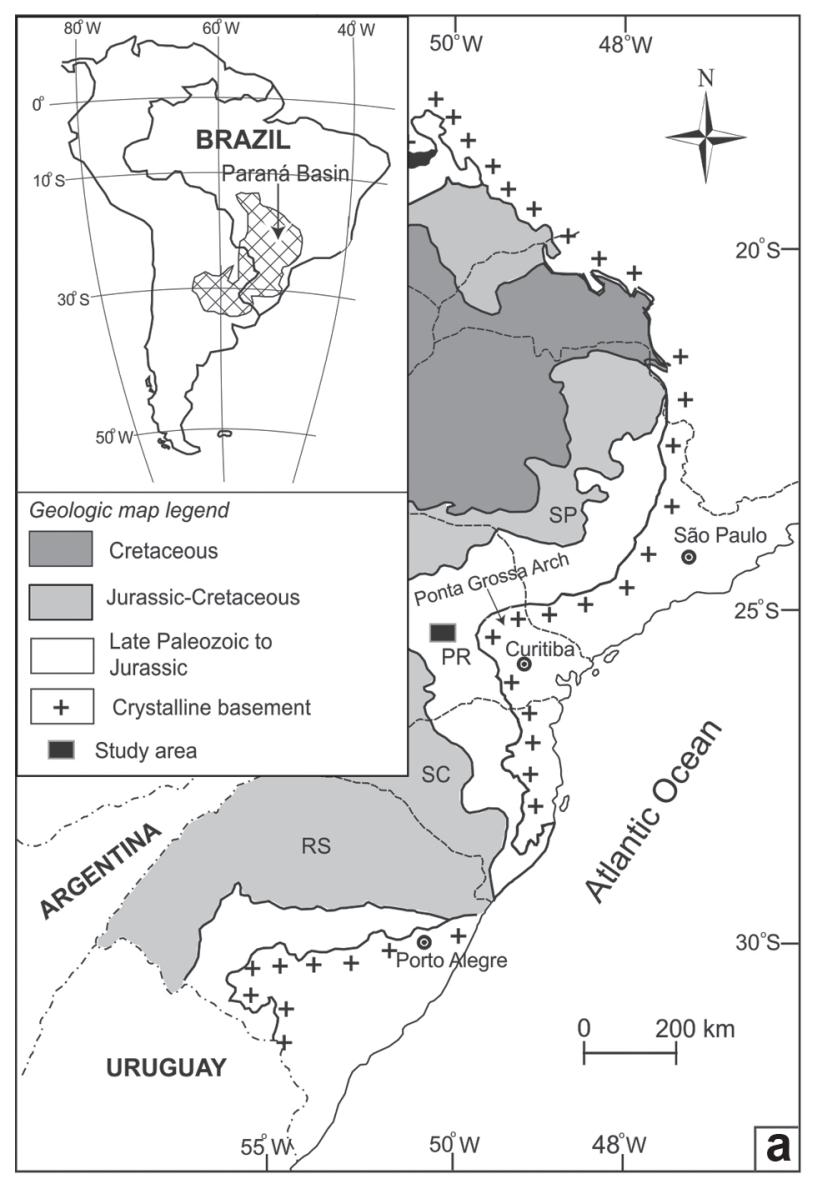

Gondwana. Hence, the geotectonic framework of the basement is characterized by several cratonic blocks and intervening mobile belts, forming a complex framework of lineaments and crustal discontinuities that influenced sedimentation patterns due to differential subsidence and uplift of the tectonic blocks (Holz et al. 2006).

Eustatic-tectonic cycles controlled the sedimentation rates in the Paraná Basin and generated a stratigraphic record that is marked by numerous subaqueous events that produced erosion as well as non-deposition surfaces. Milani and Ramos (1998) and Milani et al. (2007) described six, second order depositional sequences for this basin, ranging in age from Late Ordovician to Late Cretaceous. The stratigraphic interval studied here corresponds to

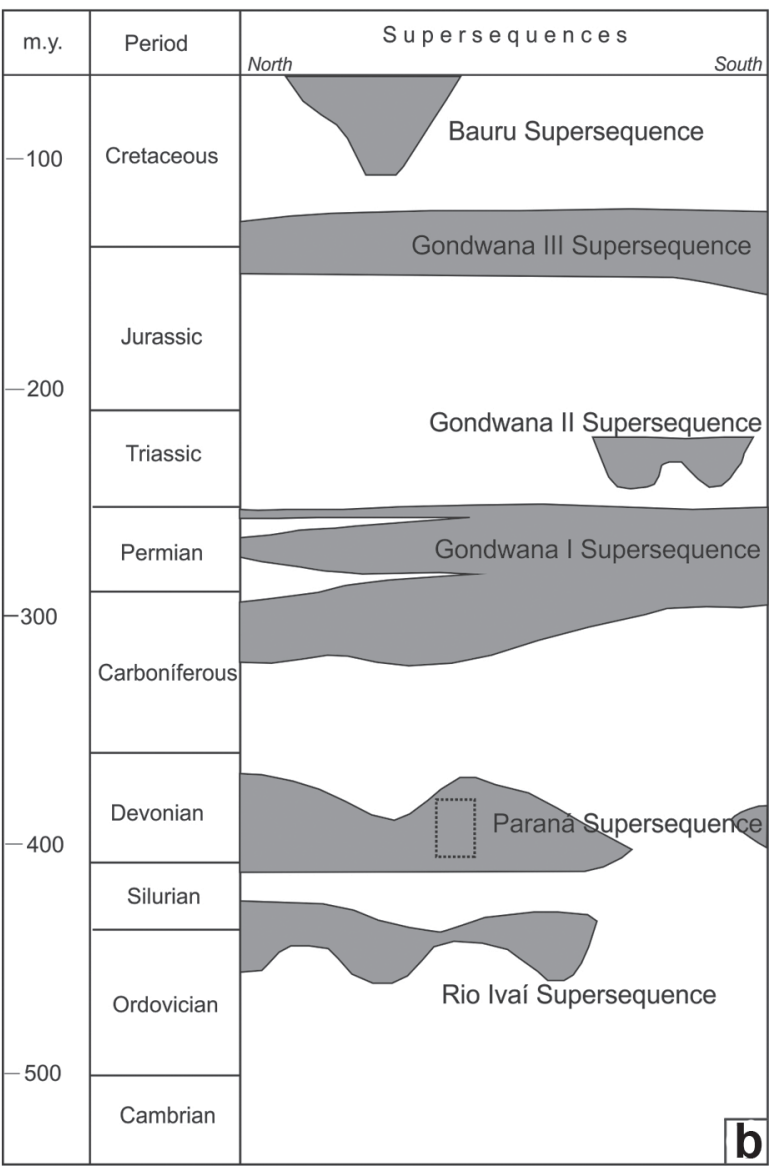

Figure 2 - a. Location map of the study area in the Paraná Basin record. b. Stratigraphic position of the interval analyzed herein (= rectangle) within the Paraná Supersequence (modified of the Milani and Ramos 1998, Milani et al. 2007). 
the second sequence of Milani et al. (2007), namely the "Paraná Supersequence," ranging from probably the latest Silurian (Pridolian) to Devonian (Figure 2b). It is a succession lithostratigraphycally divided into three formations: Furnas, Ponta
Grossa and São Domingos (Grahn et al. 2013). The new stratigraphic and paleontologic data described here was acquired from an outcrop represented by a section located in Tibagi County, Paraná State (Figure 3).

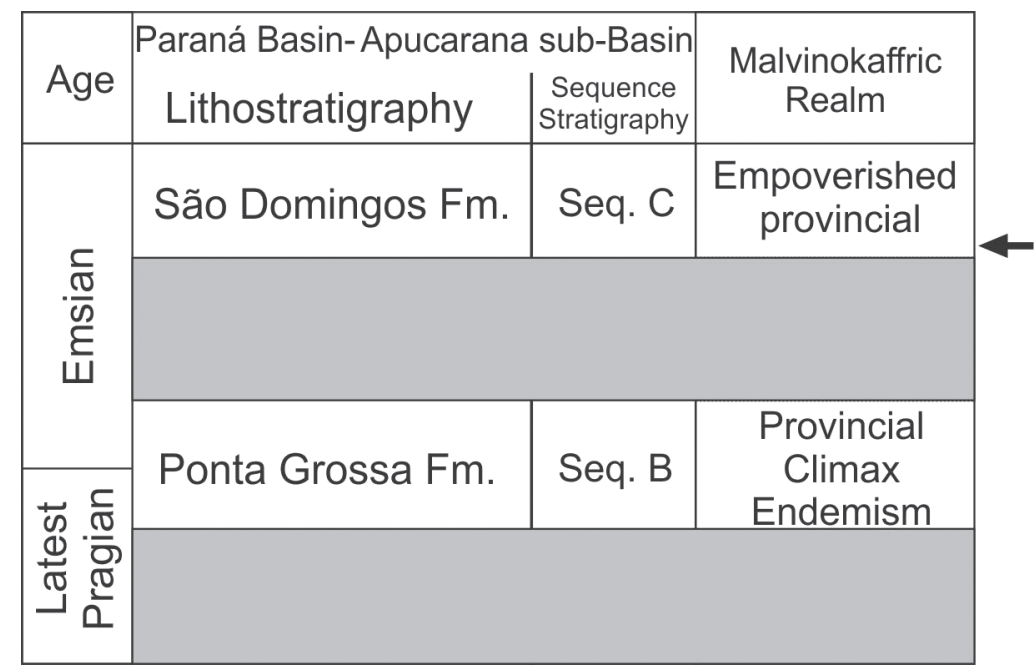

Figure 3 - Chronostratigraphic scheme for the Early Devonian interval in the Paraná Basin, Brazil (modified from Grahn et al. 2013). The arrow indicates the provenance of the shark fin remains described here.

The investigated outcrop belongs to the São Domingos Formation (Grahn 1992, Grahn et al. 2000, 2013, Mendlowicz Mauller et al. 2009), and span from the late Emsian age (Figure 3). A stratigraphic profile (Figure 4) was drawn along the Tibagi-Alto do Amparo section (Bosetti and Horodyski 2008, Horodyski 2014; see also Figure 1). The outcrops were stratigraphically stacked and correlated with the sequence framework of Bergamaschi (1999), Bergamaschi and Pereira (2001), which was updated by Grahn et al. (2013). The Devonian of the Apucarana Sub-basin was divided into six $3^{\text {rd }}$. order depositional sequences by the authors mentioned above. These sequences are numbered A-F. The studied outcrop is located within the transgressive system tract (TST) of the base of Sequence C of Horodyski (2014). According to Bergamaschi and Pereira (2001), the TST of Sequence $\mathrm{C}$ is characterized by a retrogradational facies trend, grading from fine-grained sandstones and siltstones to dark mudstones representing the maximum transgressive surface. At the topmost portion of this sequence, the progradational patterns of the facies succession are taken as an indicative of a highstand systems tract, recording the normal regression that followed the transgressive phase.

FACIES

Conglomerate and coarse to fine sandstones, siltstones and shales dominate the Lower and Middle Devonian rocks in the studied region. Neither palynofacies nor geochemical studies were undertaken to date; therefore, the facies analysis is only based either on contemporaneous or postdepositional composition, color, texture, and structure. Only the fossil-bearing facies necessary for the taphofacies analysis will be described.

The facies types summarized in Table I depicts three depositional systems characterized by seven 


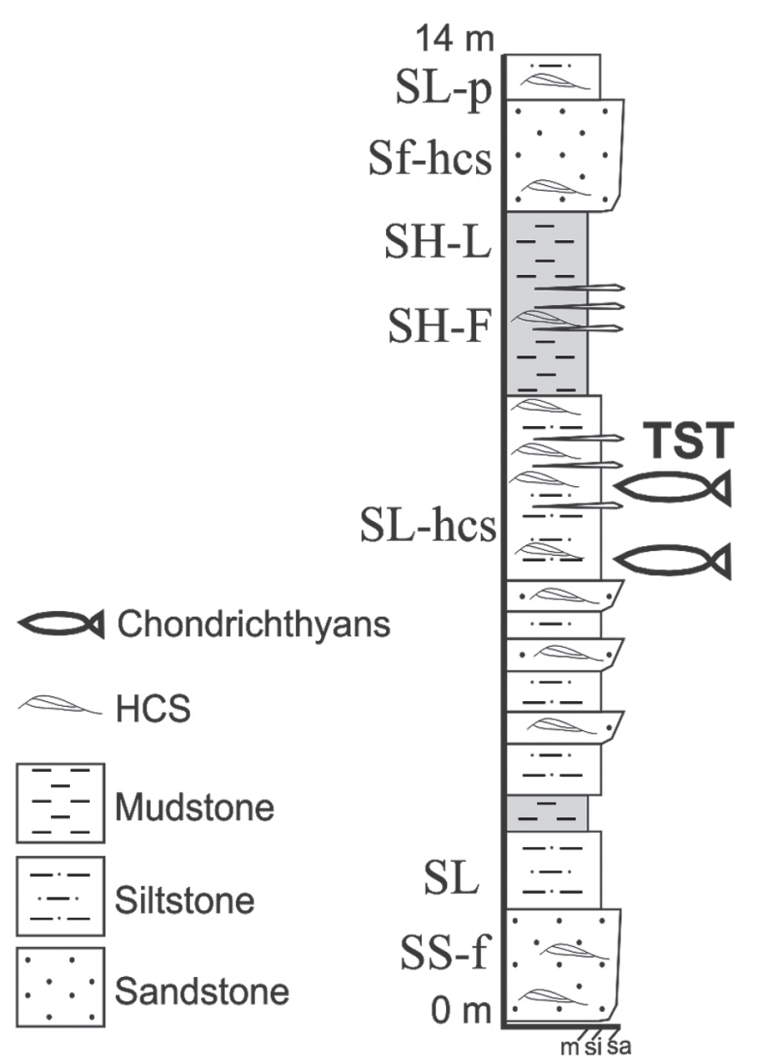

Figure 4 - Composite stratigraphic column based on a series of profiles drawn along the Tibagi-Ventania section (see Figure 1) indicating the provenance of the chondrichthyan fin remains (lithostratigraphy based on Bosetti and Horodyski (2008) and Horodyski (2014). TST = Transgressive system tract; HCS = Hummocky cross-stratification.

sedimentary processes. We interpret facies Sfhcs (fine to medium sandstones) and SS-f (fine sandstones) as associated with middle to lower shoreface above the fair-weather wave base (FWWB).

The facies SL-hcs (fine sandstones to coarse siltstones with thin interspersing sand lenses) represents the more distal shoreface zone, above the FWWB. The chondrichthyan fin remains were found in this facies.

The facies SL (massive siltstones) represents the distal shoreface to offshore transition. SL-p (siltstones often interspersed with thin sand lenses) indicates the offshore transitional zone below the lower shoreface. This region is located between the FWWB and the storm wave base level (SWB), marking the transition with the offshore, and is influenced by storm flows, represented by the thin, centimeter-scale, sand lenses locally recorded. Facies SH-f and SH-1, are interpreted as the deepest, offshore deposits with stagnant muds ( $\mathrm{SH}-$ f) and dark shales ( $\mathrm{SH}-1)$ formed by fine sediment decantation, after storm flows. This facies is found below the SWB.

\section{TAPHOFACIES}

Associated fauna: (vertebrates/chondrichthyans); (bivalved) Australospirifer iheringi Caster (1939), Derbyina withiorum Clarke (1913), Schuchertella sp., Australocoelia palmata Morris and Sharpe (1846), Australostrophia mesembria Caster (1939), Orbiculoidea sp.; and, (multielement) Crinoidea Echinasterella sp.

Taphonomic attributes: Dense pavements of entire and articulated shells, associate with a few disarticulated elements. Fragmentation, corrosion, abrasion and bioerosion are absent. Echinasterella is also abundant and complete. Fossils are oriented parallel to the bedding plane. All fossils are poorly packing throughout the matrix with no hydrodynamics preferential orientation. The chondrichthyan vertebrates are disarticulated, with only complete fins are registered, and no predation record.

Facies: (SL-hcs) occurs in fine sandstones to coarse siltstones, with thin interspersing of sand lenses. Wavy ripples or hummocky cross stratification (HCS) are present. Vertical and horizontal bioturbation occurs in association.

Interpretation and discussion (Lower shoreface storm-dominated): this taphofacies marks the lower shoreface region of the basin, above the FWWB. Fair-weather waves sporadically affected sedimentation, but no hydrodynamic selection was observed. Disarticulated brachiopods and chondrichthyan fin remains indicate post-mortem disarticulation due to bottom-level hydraulic processes and/or necrolysis at short residence 
TABLE I

Lithofacies present at the fossiliferous site illustrated in Figure 1, representing three depositional systems characterized by seven sedimentary processes. The chondrichthyan fin remains were found in the SL-hcs facies. (modified from Horodyski 2014).

\begin{tabular}{|c|c|c|c|c|c|}
\hline $\begin{array}{l}\text { FACIES } \\
\text { CODE }\end{array}$ & TEXTURE & COLOR & STRUCTURE & $\begin{array}{c}\text { DEPOSITIONAL } \\
\text { SYSTEM }\end{array}$ & $\begin{array}{c}\text { SEDIMENTARY } \\
\text { PROCESSES }\end{array}$ \\
\hline Sf-hcs & $\begin{array}{l}\text { Fine to medium } \\
\text { sandstones }\end{array}$ & $\begin{array}{l}\text { Light } \\
\text { gray }\end{array}$ & $\begin{array}{l}\text { Hummocky } \\
\text { cross- } \\
\text { beddind } \\
\text { and wavy, } \\
\text { or even } \\
\text { massive } \\
\end{array}$ & \multirow{3}{*}{$\begin{array}{l}\text { Middle to } \\
\text { lower } \\
\text { Shoreface }\end{array}$} & $\begin{array}{c}\text { Turbulent } \\
\text { mid-shoreface } \\
\text { storm- } \\
\text { influenced, } \\
\text { above FWWB }\end{array}$ \\
\hline SL-hcs & $\begin{array}{l}\text { Fine sandstones } \\
\text { to coarse } \\
\text { siltstones, with } \\
\text { thin interspersing } \\
\text { of sand lenses }\end{array}$ & $\begin{array}{l}\text { Light } \\
\text { yellowish } \\
\text { gray }\end{array}$ & $\begin{array}{l}\text { Micro- } \\
\text { Hummocky } \\
\text { cross- } \\
\text { beddind } \\
\text { and wavy }\end{array}$ & & $\begin{array}{c}\text { Lower } \\
\text { shoreface } \\
\text { storm- } \\
\text { influenced, } \\
\text { between } \\
\text { FWWB and } \\
\text { SWB }\end{array}$ \\
\hline SS-f & $\begin{array}{l}\text { Fine to medium } \\
\text { sandstones }\end{array}$ & $\begin{array}{l}\text { Light } \\
\text { gray }\end{array}$ & $\begin{array}{l}\text { Hummocky } \\
\text { cross- } \\
\text { beddind } \\
\text { and wavy }\end{array}$ & & $\begin{array}{c}\text { Middle to } \\
\text { lower } \\
\text { shoreface } \\
\text { storm- } \\
\text { dominated, } \\
\text { near or above } \\
\text { FWWB }\end{array}$ \\
\hline SL & Fine Siltstone & $\begin{array}{l}\text { Light } \\
\text { gray }\end{array}$ & Massive & $\begin{array}{c}\text { Lower } \\
\text { Shoreface to } \\
\text { Transitional } \\
\text { offshore }\end{array}$ & $\begin{array}{c}\text { Lower } \\
\text { Shoreface to } \\
\text { Transitional } \\
\text { offshore storm } \\
\text { influenced }\end{array}$ \\
\hline SL-p & $\begin{array}{l}\text { Siltstones often } \\
\text { interspersed with } \\
\text { thin sand lenses }\end{array}$ & $\begin{array}{l}\text { Light } \\
\text { gray }\end{array}$ & $\begin{array}{l}\text { Parallel } \\
\text { laminated, } \\
\text { Micro- } \\
\text { Hummocky } \\
\text { cross- } \\
\text { beddind }\end{array}$ & $\begin{array}{c}\text { Transitional } \\
\text { Offshore }\end{array}$ & $\begin{array}{l}\text { Transitional } \\
\text { offshore } \\
\text { storm- } \\
\text { influenced, } \\
\text { between } \\
\text { FWWB and } \\
\text { SWB }\end{array}$ \\
\hline SH-L & $\begin{array}{l}\text { Claystones, } \\
\text { interspersed with } \\
\text { thin sand lenses }\end{array}$ & $\begin{array}{l}\text { Dark } \\
\text { gray, } \\
\text { black }\end{array}$ & $\begin{array}{l}\text { Massive, } \\
\text { laminated }\end{array}$ & Offshore & $\begin{array}{l}\text { Offshore } \\
\text { storm- } \\
\text { influenced, } \\
\text { below SWB }\end{array}$ \\
\hline SH-F & $\begin{array}{l}\text { Mudstones,shales, } \\
\text { interspersed with } \\
\text { thin sand lenses }\end{array}$ & $\begin{array}{l}\text { Dark } \\
\text { gray, } \\
\text { black }\end{array}$ & Massive & & $\begin{array}{c}\text { Mud-stagnant } \\
\text { storm- } \\
\text { influenced, } \\
\text { below SWB }\end{array}$ \\
\hline
\end{tabular}

time. Furthermore, the occurrence of articulated Australospirifer, complete Echinasterella and chondrichthyan fin remains associated with HCS, indicates increase in the sedimentation rates (very high) with large masses of sediment deposited in a short-lived event, burying in situ some fauna 
(Echinasterella and articulated Australospirifer). Spatial and temporal mixing (Kidwell and Bosence 1991) is moderate to high in this taphofacies, generating accumulations of bioclasts of different sizes. Consequently, the high sedimentation rate deposited the remains promptly below the taphonomically active zone (inert zone) and enhanced their preservation (Davies et al. 1989, Olszewski 1999, 2004). This was possible due to the retrogradational stacking and accommodation space of the TST in the $3^{\text {rd }}$ order Devonian sequence C of the Paraná Basin.

According to Elder and Smith (1988), partial articulation of fish remains (e.g. only fins) taphonomically indicates undecayed connective tissue. Experiments developed by Smith and Elder (1985), following Schaefer (1972), show that the partial disarticulation of skeletons such as observed by Zangerl and Richardson (1963) can be the result of bacterial decay and flotation in warm waters (Elder and Smith 1988). However, during Devonian times the Malvinokaffric fauna inhabited cold, shallow marine seas at paleolatitudes ranging between $60^{\circ}-80^{\circ} \mathrm{S}$, according to Torsvik and Cocks (2013) and Melo (1988). The curious and apparently inexplicable absence of fossil fishes (prior to our recent discovery) in the Apucarana Sub-basin may be explained by selective damage caused by biostratinomic and diagenetic factors. In this particular assemblage, apparently a rapid deposition of fish carcases within a taphonomically inert zone has occurred. The quick burial prevented total decay of the cartilaginous skeletal elements (c.f. Elder and Smith 1988), but these have mostly been preserved as impressions and molds of the original material.

\section{VERTEBRATE PALEONTOLOGY \\ Phylum Chordata Haeckel, 1874 \\ Subphylum Vertebrata Lamark, 1801}

Infraphylum Gnathostomata Gegenbauer, 1874

Class Chondrichthyes Huxley, 1880

Gen. et sp. indet.

(Figs. 5-7)

Material: The three specimens, UEPG/DEGEO MPI 9959 E UEPG/DEGEO MPI 105481 and UEPG/DEGEO MPI 10709 come from an outcrop located in the vicinity of $\mathrm{Km} 220$ of the BR 153 highway and were collected within a $30 \mathrm{~cm}$ thick stratum. All the samples have been collected in situ in rocks of the São Domingos Formation, Sequence C of Bergamaschi and date from early Late Emsian. Description:

UEPG/DEGEO/MPI 9959 (Fig. 5a, b, c). The specimen represents partially articulated remains of a fin, preserved as very dark colored impressions (natural casts) of proximal and distal, rod-shaped radial elements. This specimen is $31.6 \mathrm{~mm}$ long and $0.83 \mathrm{~mm}$ wide, but the actual size of the complete fin is unknown. The preserved part of this fin shows clear radials zonation: The proximal ones, eleven of which are preserved, are mostly unsegmented and at least twice as broad as the distal ones, which are all segmented and show extensive branching. The girdle cartilages have not been preserved. UEPG/DEGEO/MPI 10709 (Fig. 6a, b): Partially articulated, but largely in disarray remains of a fin showing only impressions (natural casts) of some 60 rod-shaped radial elements. The preserved parts of this very distorted specimen measure approximately 36 x $16 \mathrm{~mm}$.

UEPG/DEGEO/MPI 10548 (Fig. 7): Poorly preserved, partially articulated remains of a fin showing only impressions (natural casts) of several radial, rod-shaped elements.

\section{DISCUSSION}

The chondrichthyan material from the Paraná Basin described here is too poorly preserved as to permit 

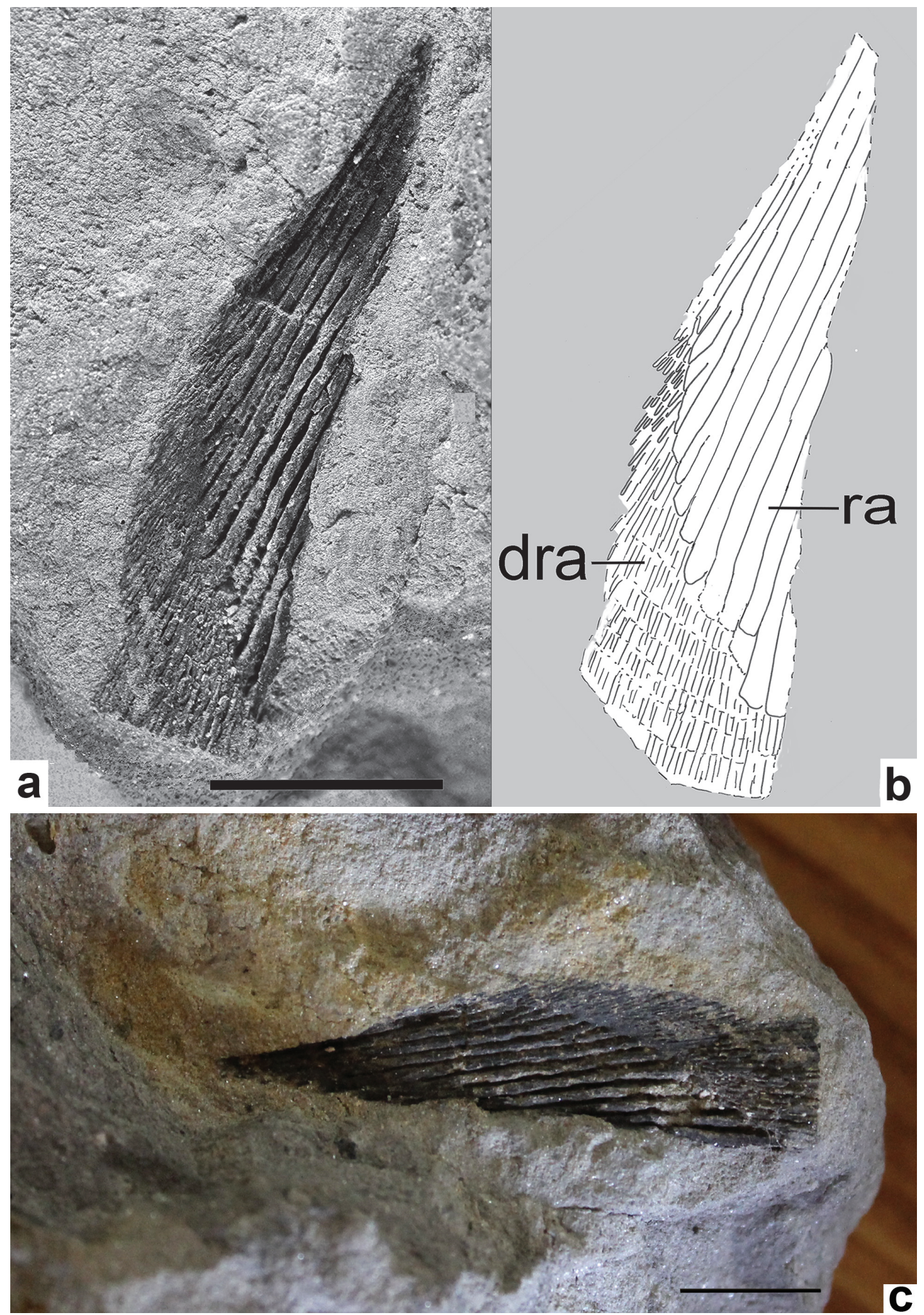

Figure 5 - UEPG DEGEO MPI9959. Partially preserved chondrichthyan fin. a. Photograph of the specimen; b. Interpretative drawing depicting proximal (ra) and distal radials (dra); c. Photograph showing the natural colours of this specimen and the rock matrix. Scale $=10 \mathrm{~mm}$ (see the colors in the online version). 


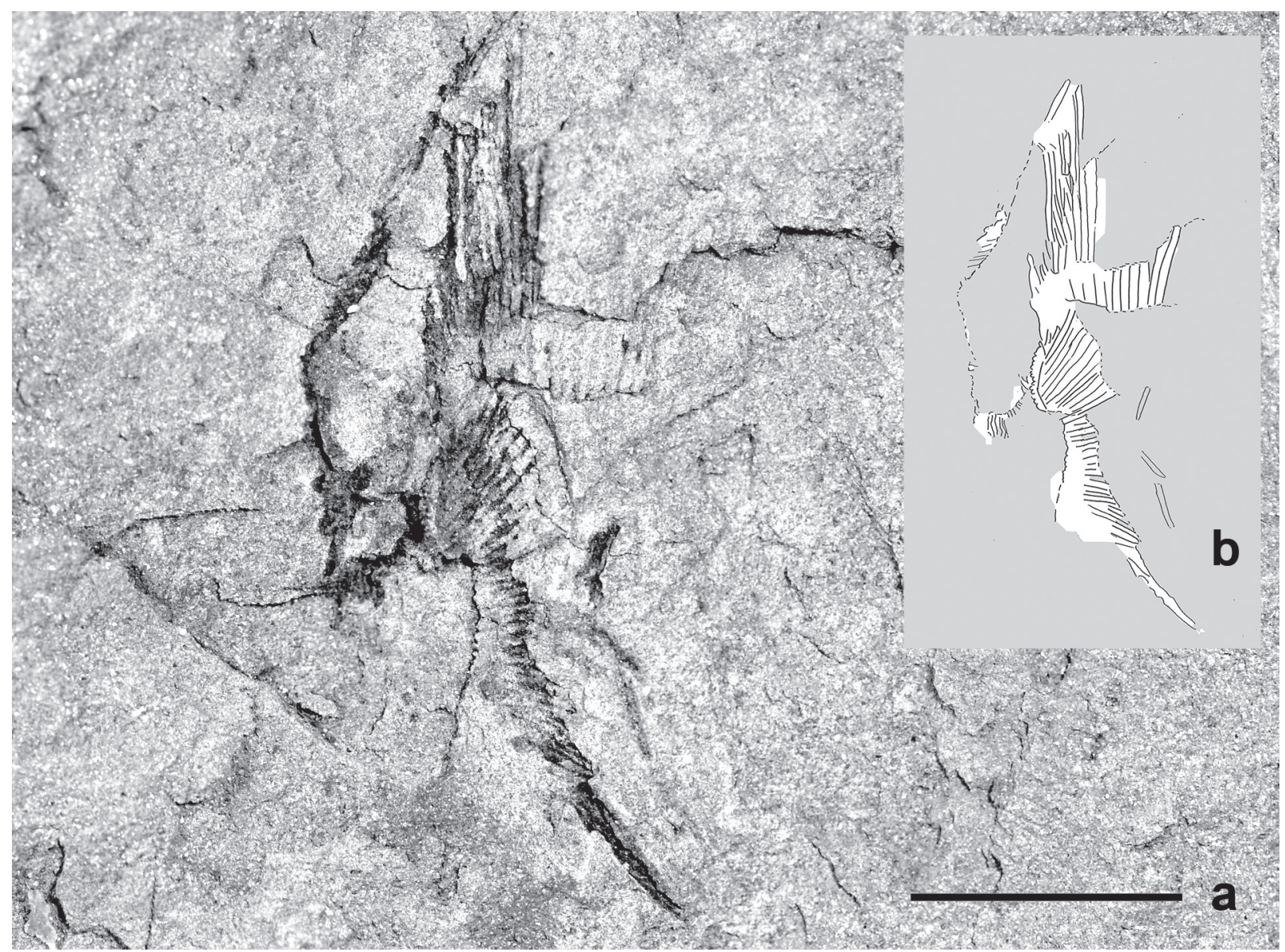

Figure 6 - UEPG/DEGEO/MPI 10709. Partially articulated remains of a chondrichthyan fin. a. Photograph of the specimen showing only impressions (natural casts) of radial elements; $\mathbf{b}$. Interpretative drawing. Scale $=10 \mathrm{~mm}$.

its attribution to any described taxa. Previously, disarticulated chondrichthyanremains were reported from the Parnaíba and the Amazon basin in Brazil as well as from other Devonian rocks elsewhere in South America. These include teeth, finspines, cartilage fragments in concretions and a braincase (Maisey 2001, Janvier and Maisey 2010). However, none of fossils described so far can be directly compared to these fin impressions found in the Devonian Paraná Basin. The only other fin remains known from South America come from Bolivia and have been attributed to the genus Zamponiopteron (Anderson et al.1999a), which apparently lacked any cartilage calcifications. According to Janvier and Maisey (2010), the closely set fin radials of the chondrichthyan Pucapampella from South Africa (a genus also occurring in the Belen Formation of Bolivia) resembles Zamponiopteron Janvier and Suárez-Riglos 1986. The systematic position of Zamponiopteron remains uncertain. Only known from 'fin plates' fossilized inside concretions which are relatively abundant in the Devonian of Bolivia, its fin radials are strangely ankilosed to the triangular plate, which make the fins resemble the 'zampoñas' or Bolivian flutes (see Janvier 2003). The radials of Zamponiopteron possess numerous longitudinal vascular grooves (Janvier 2003, fig. 4), which in our opinion preclude them from matching the anatomy of any known chondrichthyan radials and favoring a placoderm affinity instead. The 'flute-like' proximal part of the radials inside the fin plate suggests that they could articulate with placoderm basals (e.g. Carr et al. 2010, fig. 3). 
The Brazilian fin remains from the Paraná Basin differ on all accounts from Zamponiopteron. None of three specimens described here show any signs of being attached to a mineralized fin plate.

Both pectoral and pelvic fins of chondrichthyans possess long, segmented radials (e.g. Coates 2003, fig. 4). The non-preservation of basal elements hinders the identification of the anatomical positions of these three fin remains.

\section{COULD THE BRAZILIAN FIN RAYS BELONG TO PLACODERMS?}

The radial elements of placoderm fins are rarely preserved and are very poorly known. Carr et al. (2010) undertook a revision of basal and radial elements of the placoderm fins, pointing to the fact that radials are only known from two placoderm groups, namely Dunkleosteus Lehman 1956 and Gemundina stuertzi Gross 1963. Placoderm radials seem to differ from chondrichthyan radials and indeed from the material described here, by apparently being bony in nature (perichondral bone) and of equal size (Carr et al. 2010, fig. 4).

\section{PREVIOUSLY KNOWN CHONDRICHTHYAN} REMAINS FROM DE DEVONIAN OF BRAZIL

To date, chondrichthyans remains from the Devonian of Brazil have only been recorded from borehole cores and outcrops of the Amazon Basin and the Parnaíba Basin. The Early Lochkovian Manacapuru Formation of Pará has yielded isolated teeth, tooth whorls and fin spines (Janvier and Melo 1988, 1992), some of which may belong to chondrichthyans (Janvier and Maisey 2010).

The Pimenteiras Formation in Piauí (possibly Givetian in age) also contains shark remains (Janvier and Melo 1992), among which a fin spine attributed to Ctenacanthus, a bicuspid tooth similar to Leonodus and Antartilamna and a fin spine resembling Antartilamna (Maisey and Melo 2005). The occurrence of 'Devonacanthus' reported by Kegel (1953) and Santos (1961) was erroneous (Janvier and Maisey 2010).

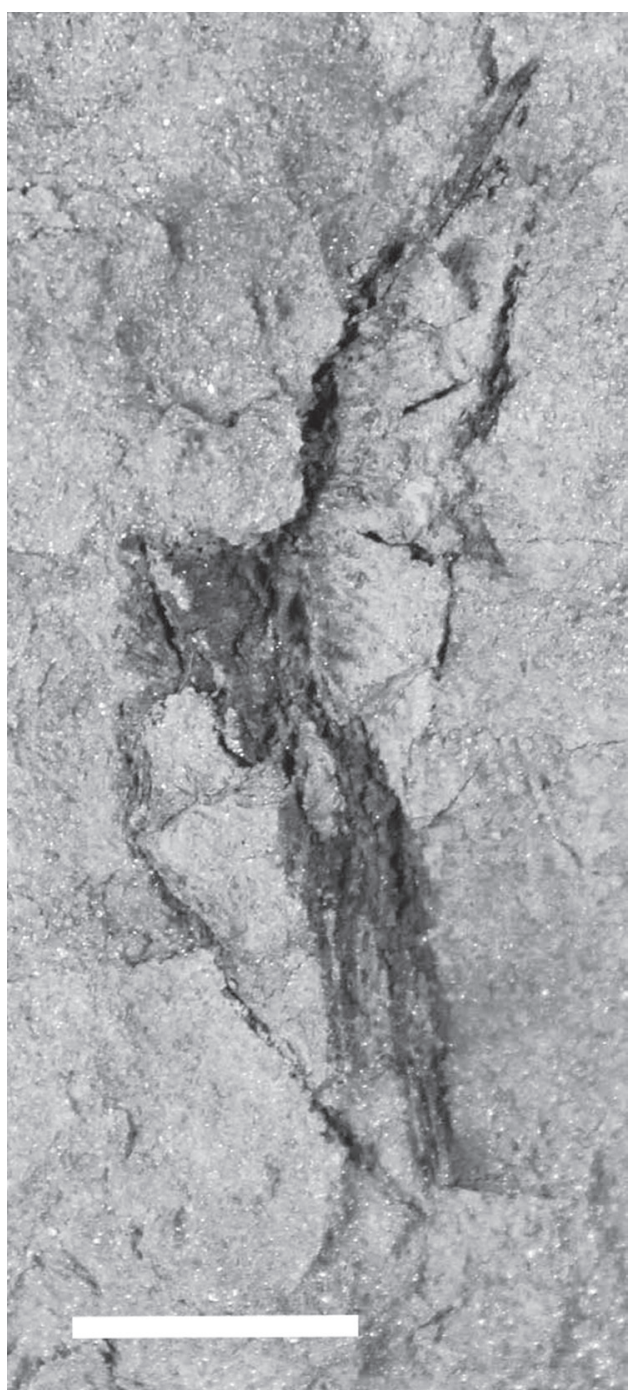

Figure 7 - UEPG/DEGEO/MPI 10548. Poorly preserved remains of a fin showing only impressions (natural casts) of radial elements. Scale $=10 \mathrm{~mm}$.

\section{DEVONIAN CHONDRICHTHYAN REMAINS FROM BOLIVIA}

The chondrichthyans Antarctilamna seriponensis Gagnier (in Gagnier et al. 1988), occurs in the Late Lochkovian//Early Pragian of Seripona, Bolivia (Janvier and Maisey 2010); The Late Emsian/Early Eifelian localities of Bolivia have yielded placoderms and chondrichthyans, the latter comprising Pucapampella sp.,?Antarctilamnidae gen. et sp. indet. and also a gnathostome of uncertain affinities, namely Zamponiopteron triangularis 
Janvier and Suárez-Riglos 1986, Z. falciformis Janvier and Suárez-Riglos 1986 and Z. spirifera Janvier and Suárez-Riglos 1986. According to Janvier and Villarroel (2000), the chondrichthyan Antarctilamna occurs the Givetian of Australia, but is also found in rocks as old as Late Emsian in Iran and Saudi Arabia. The Bolivian records (Gagnier et al. 1988, 1989) possibly range from the Emsian up to the Frasnian.

\section{DEVONIAN CHONDRICHTHYANS FROM} VENEZUELA

Antactilamnid shark remains were reported from the Middle Devonian of Maturin Basin, Venezuela by Young et al. (2000).

DEVONIAN “CHONDRICHTHYANS” FROM THE FALKLAND ISLANDS

Spines from the Devonian Islands (Lelièvre et al. 1993 ) originally described as belonging to a shark are in fact remains of a placoderm, Groenlandaspis (see Janvier and Maisey 2010).

\section{DEVONIAN CHONDRICHTHYANS FROM SOUTH} AFRICA

Anderson et al. (1999b) provided an overview of the Devonian fish faunas of South Africa is provided by Emsian and Eifelian material is scarce and fragmentary and includes placoderm acanthodian and chondrichthyan remains. Diplodont teeth attributed to phoebodonts were reported, as well as teeth of Antarctilamna.

\section{PALEOBIOGEOGRAPHIC SIGNIFICANCE AND TAPHONOMIC BIAS}

Melo (1988) provided a comprehensive correlation of the Devonian rocks in South America and Africa as well as corresponding palaeogeographical reconstructions. His figures 4 an 5 (Melo 1988, pgs. 683-4) are of special interest as they correspond to the Emsian age. They show extensive marine connections between the Paraná Basin and western
South America, but no connection with the Parnaíba and Amazon basins at the time.

Only disarticulated chondrichthyan remains have been recovered from the various Devonian fish bearing localities in South America to date. The apparent absence of an ichthyofauna of Devonian age in the Paraná Basin proved to be deceptive. The three recently discovered, partially articulated fish fins described herein provide the first evidence to suggest that sharks were indeed present in the ecosystems, although they were probably rare.

Taphonomic bias seems to have played an important role in the Devonian fossil record of the Paraná Basin. As the conditions in the Paraná Basin differ substantially from those in other Brazilian and South American basins. According to Sedorko et al. (2013), within the Paraná Basin, the interval Pridoli-Pragian is nearly devoid of body fossils. Invertebrates and ichnofossils are better known from the interval Neopraguian/EoGivetian. Although ichnofossils are abundant in both intervals, their stratigraphic distribution and taphonomy are still poorly known.

As previously pointed out by Maisey et al. (2002), 'the best-known Malvinokaffric fishes are from the Emsian-Eifelian of Bolivia, including chondrichthyans (Antarctilamna Long and Young 1995) Pucapampella, Zamponiopteron (for the latter, see Coates 2003), and placoderms (e.g., Bolivosteus apud Janvier and Suárez-Riglos 1986). Emsian Malvinokaffric vertebrates have also been described from South Africa, including forms similar or identical to Pucapampella and Zamponiopteron (Anderson et al.1999b). So far, Pucapampella, Zamponiopteron, and cf. Bolivosteus are known only from localities within the Malvinokaffric realm, suggesting that (like some of the invertebrates) they may be endemic Malvinokaffric taxa' (Maisey et al. 2002, p. 709).

Spines of the acanthodian Machaeracanthus have been reported from several Malvinokaffric sites (mainly Emsian) in Brazil (Pimenteira 
formation, Parnaíba Basin; Campos 1964, Lelièvre et al.1993, Maisey et al. 2002), Antarctica (Young 1991, Webers et al.1992) and South Africa (Lower Bokkeveld Group; Anderson et al.1999a, b). This genus has been documented in the Amazon Basin (Katzer 1897), which contains "mixed" invertebrate assemblages including Malvinokaffric and Eastern Americas and European taxa, and is considered to be a biogeographic boundary area, with a postulated Emsian-Eifelian marine connection to Bolivia or southern Peru (Melo 1988, Maisey et al. 2002).

According to Maisey et al. (2002) the chondrichthyans Pucapampella and Zamponiopteron and the rhenanid placoderm Bolivosteus are known from the Andean and South African-Malvinan provinces, but they have not yet been reported from the Falklands or Antarctica, neither have they been found in anywhere in the Brazilian province. Machaeracanthus on the other hand, was not endemic to the Malvinokaffric realm, 'its occurrence in several Malvinokaffric sites from Bolivia, the Falklands, South Africa and Antarctica makes it one of relatively few vertebrates known to have inhabited the cold, storm-dominate d circumpolar waters of that region, and it is the most widespread vertebrate known from this biogeographic realm' (Maisey et al. 2002, p. 710).

\section{CONCLUSIONS}

The recent discovery of chondrichthyan fin remains in the Emsian of the Paraná Basin is very encouraging and further fish material is now expected to be found in rocks of the same region. The material collected to date is not sufficiently well preserved to allow for taxonomic identifications at generic and species level. Also, unfavorable diagenetic conditions seem to have prevailed in most if not all the Devonian strata of the Paraná basin, which led to dissolution of biogenic apatite and other biominerals leading vertebrates and invertebrates to fossilize mostly as impressions and molds.

\section{ACKNOWLEDGMENTS}

The authors thank Dr. Leonardo Borghi (UFRJ) and Dr. Alessandra Silveira Machado (UFRJ) for the micro-CT scan tests of two of the specimens. E.P. Bosetti thanks the Conselho Nacional de Desenvolvimento Científico e Tecnológico (CNPq/ PQ 311483/2014-3) for financial support and the Plaios Group/UEPG for fieldwork; R.S. Horodyski thanks the Coordenação de Aperfeiçoamento de Pessoal de Nível Superior (CAPES) the PNPD for research grant and Dr. John Maisey (American Museum of Natural History, USA) for early discussions.

\section{REFERENCES}

ALBANESI GL, BENEDETTO JL AND GAGNIER P-Y. 1995. Sacabambaspis janvieri (Vertebrata) y conodontes del Llandeiliano temprano en la Formacion La Cantera, Precordillera de San Juan, Argentina. Bol Acad Nac Ciencias, Córdoba 60: 519-543.

ANDERSON ME, ALMOND JE, EVANS EJ AND LONG JA. 1999a. Devonian (Emsian-Eifelian) fish from the Lower Bokkeveld group (Ceres Subgroup), South Africa. J Afr Earth Sci 29: 179-194.

ANDERSON ME, LONG J, EVANS FJ, ALMOND JE, THERON N AND BENDER PA. 1999b. Biogeographic affinities of Middle and Late Devonian fishes of South Africa. Rec West Aust Mus Supplement 57: 157-168.

BERGAMASCHI S. 1999. Análise estratigráfica do SiluroDevoniano (Formações Furnas e Ponta Grossa) da sub-bacia de Apucarana, Bacia do Paraná, Brasil. Tese (Doutorado em Geociências) - Instituto de Geociências, Curso de Pós-Graduação em Geociências, Universidade de São Paulo.

BERGAMASCHI S AND PEREIRA E. 2001. Caracterização de sequências deposicionais de $3^{\circ}$ ordem para o SiluroDevoniano na sub-bacia de Apucarana, Bacia do Paraná, Brasil. Ciência-Técnica-Petróleo, seção: Exploração de Petróleo. Rio de Janeiro, vol. 20.

BOSETTIEP, GRAHN Y, HORODYSKI RS AND MAULLER PM. 2012. The first decline of the Malvinokaffric Devonian fauna in the Paraná Basin (southern Brazil and its cause; taphonomic and fossil evidence. J South Am Earth Sci 37: 228-241.

BOSETTI EP AND HORODYSKI RS. 2008. Distribuição da macropaleofauna devoniana na Seção Colunar Tibagi - Alto do Amparo, Tibagi, Estado do Paraná, Brasil. In: Sociedade Brasileira de Geologia, Congresso Brasileiro de Geologia, 44. Curitiba, Anais. Curitiba: Cherma, p. 787. 
CLARKE JM. 1913. Fósseis devonianos do Paraná. Monographias do Serviço Geológico e Mineralógico do Brasil 1: 1-353, p.1-27.

CAMPOS CWM. 1964. Estratigrafia das Bacias Paleozóica e Cretácea do Maranhão. Bol Tec Petrobras, Rio de Janeiro 7(2): 137-164.

CARR RK, LELIÈVRE H AND JACKSON GL. 2010. The ancestral morphotype for the gnathostome pectoral fin revisited and the placoderm condition. In: Elliott DK, Maisey JG, Yu X and Miao D (Eds), Morphology, Phylogeny and Paleobiogeography of Fossil Fishes, p. 107-122. Verlag Dr Friedrich Pfeil, München.

CASTER KE. 1939. A Devonian Fauna from Colombia. Bull Am Paleo 24(83): 1-218, pl. 1-14.

COATES MI. 2003. The evolution of paired fins. Theory Biosc 122: 266-287.

DAVIES DJ, POWELL EN AND STANTON RJ JR. 1989. Relative rates of shell dissolution and net sediment accumulation - a commentary: can shell beds form by the gradual accumulation of biogenic debris on the sea floor? Lethaia 22: 207-212.

ELDER RL AND SMITH GR. 1988. Fish taphonomy and environmental inference in paleolimnology. Palaeogeogr Palaeoclimatol Palaeoecol 62(1): 577-592.

FERNANDES ACS. 1996. Os icnofósseis do Ordoviciano, Siluriano e Devoniano da Bacia do Paraná. 1996. Tese (Doutorado - Programa de Pós-Graduação em Geologia), Universidade Federal do Rio de Janeiro, Rio de Janeiro, $183 \mathrm{p}$.

FERNANDES AS AND CARVALHO IS. 2002. Uma provável escavação de dipnóico na Formação Ponta Grossa, Devoniano da Bacia do Paraná. Arq Mus Nac, Rio de Janeiro 60(3): 207-211.

GAGNIER PY, PARIS F, RACHEBOEF P, JANVIER P AND SUÁREZ-RIGLOS M. 1989. Les vertébrés dévoniens de Bolivie: Donnés biostratigraphiques et anatomiques complémentaires. Bull Inst Fr Et And, Lima 18(1): 75-93.

GAGNIER PY, TURNER S, FRIMAN L, SUÁREZ-RIGLOS M AND JANVIER P. 1988. The Devonian vertebrate and mollusk fauna from Seripona (Dept. Chuquisaca, Bolivia). N Jb Geol Paläont Abh, Stuttgart (176): 269-297.

GEGENBAUER C. 1874. Grundriss der verglaichenden Anatomie. Leipzig: Verlag von Wilhelm Engelmann, 660 p.

GHILARDI RP AND SIMÕES MG. 2000. Bivalves Fósseis como indicadores da dinâmica sedimentar: um estudo de caso do Paleozóico Superior da Bacia do Paraná, Brasil. Acta Geol Leopoldensia, São Leopoldo 23(51): 3-20.

GRAHN Y. 1992. Revision of Silurian and Devonian Strata of Brazil. Palynology 16: 35-61.

GRAHN Y, MAULLER PM, BERGAMASCHI S AND BOSETTI EP. 2013. Palynology and sequence stratigraphy of three Devonian rock units in the Apucarana Sub- basin (Paraná Basin, south Brazil): additional data and correlation. Rev Palaeobot Palynol (198): 27-44.

GRAHN Y, PEREIRA E AND BERGAMASCHI S. 2000. Silurian and Lower Devonian chitinozoan biostratigraphy of the Paraná Basin in Brazil and Paraguay. Palynology 24: 143-172.

GROSS W. 1963. Gemundina stuertzi Traquair, Neuuntersuchung. Notizbl. hess. L.-Amtes Bodenforsch 91: 36-73.

HAECKEL E. 1874. Anthropogenie oder Entwicklungsgeschichte des Menschen. Engelmann, Leipzig XVI(2): 732.

HOLZ M, KÜCHLE J, PHILIPP RP, BISCHOFF AP AND ARIMA N. 2006. Hierarchy of tectonic control on stratigraphic signatures: base-level changes during the early Permian in the Paraná Basin, southernmost Brazil. J South Am Earth Sci 22: 185-204.

HORODYSKI RS. 2014. Análise tafonômica, bioestratigráfica e paleoambiental dos invertebrados marinhos da região de Tibagi-PR (Devoniano Inferior e Médio da Bacia do Paraná). Tese (Doutorado em Geociências) - Instituto de Geociências, Curso de Pós-Graduação em Geociências, Universidade Federal do Rio Grande do Sul, Porto Alegre.

HUXLEY TH. 1880. On the application of the laws of evolution to the arrangement of the Vertebrata, and more particularly of the Mammalia. Proc Zool Soc, London 43: 649-662.

JANVIER P. 2003. The Devonian vertebrates from Bolivia: new data, more enigmas. Rev Tec YPFB, La Paz 21: 25-35.

JANVIER P. 2007. The Devonian vertebrates of South America: Malvinokaffric fishes and Gondwana-Euramerica interchange. In: Diaz-Martinez E and Rabano I (Eds), $4^{\text {th }}$. European Meeting on Palaeontology and Stratigraphy of Latin America. Instituto Geologico y Minero de España, Cuadernos del Museo Geominero (8): 223-227.

JANVIER P AND MAISEY JG. 2010. The Devonian vertebrates of South America and their biogeographical relationships. In: Elliott DK, Maisey JK, Yu X and Miso D (Eds), Morphology, Phylogeny and Palaeobiogeography of Fossil Fishes. Verlag Dr Friedrich Pfeil, Munich, p. 431459.

JANVIER P AND MELO JHG DE. 1988. Acanthodian fish remains from the Silurian and Lower Devonian of the Amazon Basin, Brazil. Palaeontology, London 31(3): 771777.

JANVIER P AND MELO JHG DE. 1992. New acanthodian and chondrichthyan remains from the Lower and Middle Devonian of Brazil. N Jb Geol Paläont Mh, Stuttgart (4): 193-206.

JANVIER P AND SUÁREZ-RIGLOS M. 1986. The Silurian and Devonian vertebrates of Bolivia. Bull Inst Fr Et And, Lima 15(3-4): 73-114.

JANVIER P AND VILLARROEL C. 2000. Devonian vertebrate from Colombia. Palaeontology 43(4): 729-763.

KATZER F. 1897. Das Amazon-Devon und seine Beziehung zu den anderen Devongebieten der Erde. Sitzzungsberichte 
der Koniglich böhmischen Gesellschaft der Wisenschaften (Mathematische-naturwissenschafliche Klasse) 46: 1-50.

KEGEL K. 1953. Contribuição para o estudo do Devoniano da bacia do Parnaíba. Bol Div Geol Min, Rio de Janeiro 141: 1-18.

KIDWELL SM AND BOSENCE DW. 1991. Taphonomy and Time-Averaging of Marine Shelly Faunas: p. 116-188. In: Allison PA and Briggs DEG (Eds), Taphonomy: Releasing the data locked in the fossil record. Plenum Press, New York and London.

LAMARK J-B. 1801. Système des animaux sans vertèbres, ou tableau général des classes, des ordres et des genres de ces animaux; présentant leurs caractères essentiels et leur distribution, d'après la considération de leurs. Paris, Detreville VIII: 1-432.

LANGEFW. 1967. Biostratigraphic subdivision and correlation of the Devonian in the Paraná Basin. In: Bigarella JJ (Ed), Problems in Brazilian Devonian geology. Bol Paranaense Geocien, Curitiba 21/22: 63-98, pl.1-5, ill.

LEHMAN JP. 1956. Les arthrodires du Dévonien supérieur du Tafilalt (Sud marocain). Not Mem Ser Féologique Maroc 129: 1-70.

LELIÈVRE H, JANVIER P AND BLIECK A. 1993. Silurian-Devonian vertebrate biostratigraphiy of Western Gondwana and related terranes (South America, Africa, Armorica-Bohemia, Middle East). In: Long J (Ed), Palaeozoic vertebrate biostratigraphy and Biogeography, p. 139-173. Belhaven Press.

LEONARDI G. 1983. Notopus petri, n. gen., sp.; an amphibian imprint in the Devonian of Paraná, Brazil. Geobios 16: 233-239.

LONG JA AND YOUNG GC. 1995. Sharks from MiddleLate Devonian Aztec Siltstone, southern Victoria Land, Antarctica. Rec West Austral Mus 17: 287-308.

MAISEY JG. 2001. A primitive chondrichthyan braincase from the Middle Devonian of Bolivia. In: Ahlberg P (Ed), Major events in early vertebrate evolution, p. 263-288.

MAISEY JG, BORGUI L AND CARVALHO MGP DE. 2002. Lower Devonian fish remains from the Falkland Islands. J Vert Paleont 22(3): 708-711.

MAISEY JG AND MELO JHG. 2005. Some Middle Devonian (Eifelian/Givetian) fish remains from the Pimenteiras Formation of the Parnaíba Basin, Northeastern Brazil. Arq Mus Nac, Rio de Janeiro 63: 495-505.

MELO JH DE. 1988. The Malvinokaffric real in the Devonian of Brazil. Mem Canadian Soc Petrol Geol (14): 669-703.

MENDLOWICZ MAULLER P, GRAHN Y AND MACHADO CARDOSO TR. 2009. Palynostratigraphy from the Lower Devonian of the Paraná Basin, south Brazil, and a revision of contemporary chitinozoan biozones from western Gondwana. Stratigraphy 6: 313-332.

MILANI EJ, MELO JHG, SOUZA PA, FERNANDES LA AND FRANÇA AB. 2007. Bacia do Paraná. Bol Geociências Petrobras 15: 265-287.
MILANI EJ AND RAMOS VA. 1998. Orogenias paleozóicas no domínio sul-ocidental do Gondwana e os ciclos de subsidência da Bacia do Paraná. Rev Bras Geociênc 28(4): 527-544.

MILLER KB, BRETT CE AND PARSONS KM. 1988. The paleoecologic significance of storm-generated disturbance within a Middle Devonian muddy epeiric sea. Palaios 3: 35-52.

MORRIS J AND SHARPE D. 1846. Description of eight species of brachyopodous shells from the Palaeozoic rocks of the Falkland Islands. Quart J Geol Soc 2: 274-278, pls. $\mathrm{X}$ - XI.

OLIVEIRA EP. 1912. O terreno devoniano do sul do Brasil. Escola de Minas de Ouro Preto 14: 31-41.

OLSZEWSKI TD. 1999. Taking advantage of time-averaging. Paleobiology 25: 226-238.

OLSZEWSKITD. 2004. Modeling the influence of taphonomic destruction, reworking, and burial on time-averaging in fossil accumulations. Palaios 19: 39-50.

PETRI S. 1948. Contribuição ao estudo do Devoniano paranaense. Bol da Div Geol Mineral. Rio de Janeiro 129: 125.

ROČEK Z AND RAGE J-C. 1994. The presumed amphibian footprint Notopus petri from the Devonian: a probable starfish trace fossil. Lethaia, Oslo 27(3): 241-244.

SANTOS RS. 1961. Peixes fósseis do DevonianoInferior de Picos, Estado do Piauí. An Acad Bras Cienc 33(3/4): XXXII (Resumo), Rio de Janeiro.

SCHAEFER W. 1972. Ecology and Palaeoecology of Marine Environments. Oliver and Boyd, Edinburgh, $568 \mathrm{p}$.

SEDORKO D, GUIMARÃES NETO R AND BOSETTI EP. 2013.Terr@Plural, Ponta Grossa 7(Número Especial): 59-73.

SIMÕES MG AND GHILARDI RP. 2000. Protocolo tafonômico/paleoautoecológico como ferramenta nas análises paleossinecológicas de invertebrados: exemplos de aplicação em concentrações fossilíferas do Paleozóico da Bacia do Paraná, Brasil. Pesquisas em Geociências 27(2): 3-13.

SMITH GR AND ELDER RL. 1985. Environmental interpretation of burial and preservation of Clarkia fishes. In: Smiley CJ (Ed), Late Cenozoic History of the Pacific Northwest. Pac Div Am Assoc Adv Sci, Calif Acad Sci, San Francisco, Calif, p. 8593.

SPEYER SE AND BRETT CE. 1986. Trilobite taphonomy and Middle Devonian taphofacies. Palaios 1: 312-327.

SPEYER SE AND BRETT CE. 1988. Taphofacies models for epeiric sea environments: Middle Paleozoic examples. Palaeogeogr Palaeoclimatol Palaeoecol 63: 222-262.

TOLEDO CEV AND BERTINI R. 2005. Occurrences of fossil dipnoiformes in Brazil and its stratigrafic and chronological distributions. Rev Brasil Paleontolog 8(1): 47-56.

TORSVIK TH AND COCKS LRM. 2013. Gondwana from top to base in space and time. Gondwana Res 24(3): 9991030 . 
WALKER RG AND PLINT AG. 1992. Wave and storm dominated shallow marine systems. In: Walker RG and James NP (Eds), Facies Models - Response to sea level change, p. 219-238. Geological Association of Canada, Canada.

WEBERS GFB, GLENISTER JP AND YOUNG G. 1992. Devonian fossils from the Ellsworth Mountains, West Antarctica. p. 269-278. In: Webers GF, Craddock C and Splettsoesser JF (Eds), Geology and Palaeontology of the Ellsworth Mountains, West Antarctica. Geological Society of America, Boulder.

YOUNG G. 1991. Fossil fishes from Antarctica. In: Tingley RJ (Ed), The Geology of Antarctica. Oxford Monographs on Geology and Geophysics, Claredon Press (17): 538-567.
YOUNG GC, MOODY JM AND CASAS JE. 2000. New discoveries of Devonian vertebrates from South America, and implications for Gondwana-Euramerica contact. C R Acad Sci Paris, Sciences de la Terre et des planets (331): 755-761.

ZABINI C, HOLZ M, BOSETTI E, MATSUMURA WMK AND HORODYSKI RS. 2012. Sequence stratigraphy and taphonomy signatures of marine invertebrates: a Devonian (Pragian-Eifelian) example of the Paraná Basin, Brazil. J South Amer Earth Sci 33: 8-20.

ZANGERL R AND RICHARDSON ES. 1963. The paleoecological history of two Pennsylvanian black shales. Fieldiana, Geol Mem 4: 1-352. 